\title{
A Monetary Model of Factor Utilisation
}

\author{
Katharine S. Neiss ${ }^{\dagger}$ \\ Bank of England
}

\author{
Evi Pappa \\ Universitat Pompeu Fabra
}

Original Version: October 2000

This Version: December 2001

\begin{abstract}
:
We investigate the propagation mechanism of monetary shocks in an otherwise standard sticky price model, modified to incorporate factor hoarding in the form of variable capital utilisation rates and labour effort. In contrast to previous studies, we find that real effects of monetary shocks can be generated at relatively low degrees of nominal rigidity. Factor hoarding enriches the propagation mechanism by flattening the marginal cost responses to monetary shocks. The assumption of labour hoarding is crucial for generating persistence, while the assumption of variable capital utilisation allows us to generate realistic investment volatility without having to introduce capital adjustment costs.
\end{abstract}

JEL Classification: E51,E22

Keywords: Factor hoarding, propagation of monetary shocks, persistence

We thank Mark Astley, Larry Ball, Jordi Gali, Jens Larsen, Ed Nelson and Fergal Shortall for helpful discussions. We are particularly indebted to Ed Nelson for his help in coding stochastic simulations.

${ }^{\dagger}$ Analyst, Structural Economic Analysis Division, Monetary Analysis, Bank of England, Threadneedle Street, London EC2R 8AH, United Kingdom.

Tel: +44 2076014588 Fax: +44 2076015018

Email: katharine.neiss@ bankofengland.co.uk

"Department of Economics, London School of Economics and Political Science, Houghton Street, London WC2A AE, United Kingdom

Tel: +44 2079557584 Fax: +44 2079551840

Email:p.pappa@1se.ac.uk 
The current workhorse for the study of monetary policy is a sticky-price dynamic stochastic general equilibrium model. ${ }^{1}$ Calvo (1983) and Rotemberg (1997) provide the theoretical background for introducing nominal price rigidities within a tractable, representative firm framework. As shown by Roberts (1995), this framework implies a Phillips curve, known as the 'New Keynesian' Phillips curve, that has become standard in sticky price models (McCallum, 1997). A central component of 'New Keynesian' models is that monetary shocks have real effects. Recent work by Kiley (1998) and Chari, Kehoe and McGrattan (2000), however, has shown that the predictions regarding persistence in the Calvo, partial price adjustment model do not generally carry over to more realistic models of Taylor - type (1979) price staggering. ${ }^{2}$ Moreover, they argue that the only way to induce protracted effects of monetary policy on real variables is to assume a high degree of price stickiness. This is a rather unsatisfying mechanism given the controversy surrounding the existence of price adjustment costs. And even if there is agreement that these costs exist, there is no agreed framework for modelling the costs that firms face for changing their price. $^{3}$

One way to address these criticisms is to reduce the model's reliance on nominal rigidities for the propagation of shocks, and assume a low degree of nominal rigidity. In doing so, however, the propagation mechanism to monetary shocks in a standard model is essentially eliminated. In a seminal paper, Ball and Romer (1990) suggest that real rigidities have a crucial role in amplifying nominal rigidities and the nonneutrality of shocks. Indeed these arguments are echoed in work by Romer (1996), Christiano, Eichenbaum, and Evans (1997), Kiley (1998), and Chari, Kehoe, and McGrattan (2000). The hope is that real rigidities, coupled with small nominal rigidities, are enough to induce non-neutral effects of monetary policy shocks. In addition, real rigidities have the added benefit of bringing the predictions of a partial price adjustment model closer in line with more realistic, but cumbersome, staggered price setting models as noted by Kiley (1998).

A related issue is the importance of fluctuations in investment in the transmission mechanism of monetary policy. Many New Keynesian sticky price models assume an

\footnotetext{
${ }^{1}$ See for example Rotemberg and Woodford (1997) and McCallum and Nelson (1999).

${ }^{2}$ See for example Jeanne (1997).

${ }^{3}$ For example, a recent paper by Mankiw and Reis (2001) looks at sluggish price adjustment in a model where there are costs to acquiring information. Mankiw (2000) reviews some more general
} 
exogenous capital stock (Rotemberg and Woodford, 1997, McCallum and Nelson, 1999). The behaviour of these models with endogenous capital formation has been a key area of recent research (King and Watson 1996, King and Wolman 1996, Yun 1996, Woodford 2000, Casares and McCallum 2000). A problem with sticky price models with capital, however, is that output becomes excessively responsive to monetary shocks if capital can be costlessly adjusted. However, Chari, Kehoe, and McGrattan (2000) note that the introduction of capital nevertheless reinforces the lack of persistence in staggered pricing and partial price adjustment models. In order to generate realistic dynamics, sticky price models typically introduce a real rigidity in the form of capital adjustment costs-- in essence, making these models behave similarly to sticky price models with no capital.

This paper investigates the persistence properties of a sticky-price variant of Burnside and Eichenbaum's (1996) model with capital and time-varying factor utilisation. ${ }^{4}$ Burnside and Eichenbaum's seminal paper showed that i.i.d. shocks to productivity growth generate persistence in a real business cycle model with time-varying factor utilisation. That paper was motivated in part by criticisms of the RBC literature, notably by Cogley and Nason (1995), that they lack internal propagation mechanisms. We investigate whether the persistence properties of the model carry over to nominal shocks in a sticky-price environment. We find that the introduction of time varying factor utilisation can generate a real and persistent response to monetary policy shocks, even at relatively low levels of nominal rigidity. ${ }^{5}$ Unlike sticky-price models with capital, time-varying factor utilisation elicits an even greater response of investment to policy shocks, and as such allows for a reduction in the assumed degree of price rigidity without sacrificing the persistence properties of the model. In addition, at low levels of nominal rigidity, we are able to generate realistic investment volatility without having to introduce capital adjustment costs.

weaknesses associated with the New Keynesian Phillips curve, such as the counter-intuitive predicted relationship between expected inflation and output as noted by Ball (1994).

${ }^{4}$ Fagnart, Licandro, and Portier (1999) investigate the implications of capacity utilisation in a model with explicit micro-foundations, and find that capacity utilisation is an important mechanism for the propagation of technology shocks. Although the depreciation through use assumption in the BE model is a crude way of modelling capacity utilisation, the authors find that it generates similar predictions to those based on a more micro-founded approach.

${ }^{5}$ A related paper by Cook (1999) looks at the propagation mechanism of a real business cycle model with time varying factor utilisation and dynamic complementarities in a limited participation model. He finds that a transitory liquidity shock has a persistent effect on real output, and that time varying factor utilisation plays an important role in augmenting the propagation mechanism. 
We compare our results to sticky-price models with capital to explore more generally the relationship between nominal price rigidity and firms' ability to adjust capital services. The introduction of variable capital utilization and capital hoarding substantially decreases the instantaneous responsiveness of real marginal costs to changes in output. In standard models with variable labour input and predetermined capital, firms face sharply rising short-run marginal costs. Since prices and capital are predetermined, firms increase output by hiring more labour in response to unanticipated shocks, which in turn drives up real wages and hence marginal cost. As a result, real marginal costs are highly responsive to changes in output. In a model of variable factor utilization, firms can increase both capital and labour services in response to unanticipated shocks. Although, wages rise to reflect the increase in labour, the marginal increase in production by varying capital utilization is higher than the marginal cost of increasing the effective capital input, because firms hoard capital in equilibrium. As a result, output increases are much larger than the increases in real marginal costs. This is the mechanism that a model of time varying factor utilisation exploits to generate real effects of monetary shocks. In addition, the effect of utilization on the depreciation of capital coupled with the assumption of labour hoarding enables us to generate persistence at low degrees of nominal rigidity.

In a related paper, Christiano, Eichenbaum and Evans (2001) use staggered wage contracts and variable capital utilisation to generate both output persistence and inflation inertia. Labour market rigidities coupled with variable capital utilisation in their model and in the one presented here introduces a strong internal propagation mechanism. In our model, labour market 'rigidities' are represented by labour hoarding (i.e. firms cannot adjust employment in heads instantaneously), whereas Christiano et. al (2001) assume staggered wage contracts. Their model includes additional departures from the standard general equilibrium model, such as habit persistence in consumption and investment adjustment costs, in order to account for the response of consumption and investment to a monetary policy shock. For a small degree of price rigidity, the prediction of our model for the behaviour of output and investment in response to a nominal shock coincides with theirs. However, unlike Christiano et al. (2001), we are unable to generate inertia in inflation. This is due to the assumption of wage flexibility in our model.

The paper is organised as follows. In Section 2 we describe our benchmark model, Section 3 discusses the calibration and impulse responses, Section 4 considers other 
sticky-price models both with and without capital, Section 5 compares the various model statistics, Section 6 explores the mechanisms that generate persistence in our benchmark model, and Section 7 concludes.

\section{A model of time-varying factor utilisation}

This section describes a sticky-price variant of Burnside and Eichenbaum's (1996) model with capital formation and time-varying effort and capital utilisation rates.

The economy consists of infinitely-lived agents, firms, and a government sector. Households and firms optimise intertemporally and have rational expectations. As is usually assumed in the New Keynesian literature, monopolistic firms set their price to maximise profits, but cannot always adjust them instantaneously in response to changing economic conditions. Nominal price stickiness is modelled as in Calvo's (1983) specification of partial price adjustment. Firms produce a continuum of differentiated goods, which are aggregated to produce a single composite good that can be used for consumption and investment. Households derive utility from the transactions services provided by real balances, and the economy is subject to shocks to real productivity, government spending and the nominal money stock. The key feature of the model is factor hoarding by firms. Following Burnside and Eichenbaum, we assume that the technology for producing differentiated goods depends on capital and labour services. The latter is defined as labour effort times total hours worked. The former is defined as capital utilisation times the existing physical stock of capital. The rate at which capital depreciates is assumed to be a function of the capital utilisation rate. Moreover, the equilibrium amount of labour units employed (measured in heads) in production is assumed to be chosen prior to the realisation of period $t$ shocks. As a result, in equilibrium, firms may over- or underutilise (e.g. hoard) capital and labour. 


\subsection{Households}

Households consume a continuum of differentiated goods indexed by $i \in[0,1]$. The composite consumption good $\left(C_{t}\right)$, which is defined by a Dixit-Stiglitz aggregate over a multiplicity of goods, and price index $\left(P_{t}\right)$ are defined as:

$$
C_{t}=\left[\int_{0}^{1} c_{t}(i)^{\frac{\rho-1}{\rho}} d i\right]^{\frac{\rho}{\rho-1}}
$$

and

$$
P_{t}=\left[\int_{0}^{1} p_{t}(i)^{1-\rho} d i\right]^{\frac{1}{1-\rho}}
$$

where the elasticity of substitution between differentiated goods, $\rho$, is assumed to be greater than one.

The economy is inhabited by a large number of households, each of which has preferences defined over the composite consumption good $\left(C_{t}\right)$, real money balances $\left(M_{t}^{d} / P_{t}\right)$, and leisure. Following Hansen (1985) and Rogerson (1988), we assume that agents face a lottery, which determines whether or not they will be employed. The probability of employment in time $t$ is given by $\left(N_{t}\right)$. The proportion $\left(1-N_{t}\right)$ of the population not currently employed derive leisure from their total time endowment $\tau$. Those who are currently employed work a fixed shift length $h$, and incur a fixed cost of commuting $\chi$ out of their total time endowment. Whether time spent at work contributes to leisure depends on the level of effort $\left(e_{t}\right)$ expended. Effective hours of leisure for the fraction of the population currently employed are thus given by $\tau-\chi-h e_{t}$.

The proportion of the population currently employed, $N_{t}$, is assumed to be predetermined. Following Burnside, Eichenbaum, and Rebelo (1993), this formulation introduces labour-hoarding and captures the notion that employment in 
heads cannot be immediately adjusted in response to unanticipated shocks, and that firms must make employment decisions conditional on their view about the future state of demand and technology.

The representative household chooses a sequence of consumption, effort, nominal money balances and one-period bond holdings $\left(B_{t+1}\right)$, capital $\left(K_{t+1}\right)$, utilisation $\left(U_{t}\right)$, and employment $\left(N_{t+1}\right)$, to maximise lifetime utility:

$$
E_{t} \sum_{j=0}^{\infty} \beta^{j}\left[\ln C_{t+j}+\theta N_{t+j} \ln \left(\tau-\chi-h e_{t+j}\right)+\theta\left(1-N_{t+j}\right) \ln (\tau)+\frac{1}{1-\varepsilon}\left(\frac{M_{t+j}^{d}}{P_{t+j}}\right)^{1-\varepsilon}\right]
$$

subject to a series of period budget constraints:

$$
P_{t+j} C_{t+j}+P_{t+j} I_{t+j}+M_{t+j}^{d}+B_{t+j+1}=P_{t+j} w_{t+j} N_{t+j} e_{t+j}+P_{t+j} r_{t+j} U_{t+j} K_{t+j}+M_{t-1+j}^{d}+\left(1+R_{t-1+j}\right) B_{t+j}+V_{t+j}+\Gamma_{t+j}
$$

$\forall j=0,1, \ldots, \infty$, where $\theta>0, \varepsilon>0$, and $\beta \in(0,1)$. In the budget constraint, $R_{t-1+j}$ denotes the net nominal interest rate, $r_{t+j}$ denotes the rental rate on capital services, and $V_{t+j}$ and $\Gamma_{t+j}$ denote lump sum firm profits and government transfers, respectively. Investment $\left(I_{t+j}\right)$ is related to the capital stock by:

$$
I_{t+j}=K_{t+1+j}-\left(1-\delta U_{t+j}^{\phi}\right) K_{t+j}
$$

Following Greenwood, Hercowitz and Huffman (1988) the evolution of capital assumes that using capital more intensively increases the rate at which capital depreciates, where $\delta \in[0,1)$ and $\phi>1$. The parameter $\phi$ is negatively related to the responsiveness of utilisation to shocks, and is interpreted as the elasticity of depreciation with respect to utilisation. For very large values of $\phi$, the negative effects of utilisation on depreciation dominate the positive effects of utilisation on output, and firms choose to keep utilisation constant.

The first order conditions for the representative household are given in Appendix 1. 


\subsection{Firms}

There is a continuum of monopolistically competitive firms, indexed by $i \in[0,1]$. Each firm $i$ chooses its factor inputs, labour services $\left(N_{t} e_{t}\right)$ and capital services $\left(K_{t} U_{t}\right)$, in order to minimise costs of producing a given level of output $\left(\bar{Y}_{t}\right)$ :

$$
w_{t} N_{t} e_{t}+r_{t} K_{t} U_{t}
$$

subject to its technological constraint on production: ${ }^{6}$

$$
\bar{Y}_{t} \leq\left(K_{t} U_{t}\right)^{1-\alpha}\left(N_{t} h e_{t} X_{t}\right)^{\alpha}
$$

where $0<\alpha<1$. The process for the level of technology is assumed to follow a logarithmic random walk with drift:

$$
X_{t}=X_{t-1} \exp \left(\gamma+v_{t}\right)
$$

where $v_{t} \sim \operatorname{iid}\left(0, \sigma_{A}\right)$. The firm chooses labour and capital services such that:

$$
\begin{gathered}
w_{t}=\frac{\alpha Y_{t} m c_{t}}{N_{t} e_{t}} \\
r_{t}=\frac{(1-\alpha) Y_{t} m c_{t}}{K_{t} U_{t}}
\end{gathered}
$$

where $m c_{t}$ denotes the unit cost function, or real marginal cost.

As described in King and Wolman (1996) and Yun (1996), each firm $i$ is allowed to reset its price $\left(P_{t}^{i}\right)$ according to a stochastic time-dependent rule that depends on receiving a signal at a constant random rate $(1-\eta)$. The parameter $\eta$ governs the degree of nominal price rigidity: as $\eta$ approaches 0 , prices become perfectly flexible; as $\eta$ approaches 1 , firms charge a fixed price. Producers face an idiosyncratic risk

\footnotetext{
${ }^{6}$ An alternative model of factor hoarding, due to Bils and Cho (1994), relates capital utilisation directly to effort in the production function. This specification has perhaps greater intuitive appeal in that increases in total hours worked automatically raises the degree to which the existing physical capital stock is utilised. However, Burnside and Eichenbaum note that the propagation mechanism of this alternative model of factor hoarding is much weaker. Although the specification adopted in the present paper does not mechanically link utilisation to effort, they will nevertheless move together in response to shocks since they are assumed to be complements in production.
} 
due to the uncertainty of price adjustment. The probability that the price set at time $t$ still prevails at $t+j$ is given by $\eta^{j}$. Each firm with an opportunity to change its price will choose it to maximise profits, taking aggregate output $\left(Y_{t}\right)$, the aggregate price level $\left(P_{t}\right)$, and nominal marginal cost $\left(M C_{t}^{i}\right)$ as given:

$$
E_{t} \sum_{j=0}^{\infty} \Lambda_{t, t+j} \eta^{j}\left[\widetilde{P}_{t}^{i}-M C_{t+j}^{i}\right] Y_{t+j}^{i}
$$

subject to demand for its $\operatorname{good}\left(Y_{t}^{i}\right)$ :

$$
Y_{t+j}^{i}=\left[\frac{P_{t}^{i}}{P_{t}}\right]^{-\rho} Y_{t+j}, \forall j=0,1, \ldots, \infty
$$

The solution to this problem yields the firm's optimal price $\left(\widetilde{P}_{t}^{i}\right)$, which is given by:

$$
\widetilde{P}_{t}^{i}=\frac{\rho}{\rho-1} \frac{E_{t} \sum_{j=0}^{\infty} \Lambda_{t, t+j} \eta^{j}\left[Y_{t+j}^{i} m c_{t+j}^{i}\right]}{E_{t} \sum_{j=0}^{\infty} \Lambda_{t, t+j} \eta^{j} Y_{t+j}^{i}}
$$

In the above relationship, $\frac{\rho}{\rho-1}$ is the steady state mark-up, or the inverse of the steady state real marginal cost. Equation (1.13) illustrates that the optimal price depends on current and expected future demand and real marginal cost $\left(m c_{t}^{i}\right)$. Intuitively, firms know that the price they set today may also apply in future periods, so the expected state of the economy influences the price they choose today.

Given the pricing decisions of each firm $i$, the aggregate price index evolves according to:

$$
P_{t}=\left[\eta P_{t-1}^{1-\rho}+(1-\eta) \widetilde{P}_{t}^{1-\rho}\right]^{\frac{1}{1-\rho}}
$$


The aggregate price level is therefore a weighted average of prices set in $t-1$, to reflect the fact that some firms cannot change their price in period $t$, and the optimal period $t$ price, to reflect the fact that the remaining firms can reset their price.

\subsection{Government}

Real government purchases of goods and services are modelled as an exogenous stochastic process:

$$
G_{t}=X_{t} \exp \left(g_{t}\right)
$$

where $g_{t}=\mu\left(1-\rho_{g}\right)+\rho_{g} g_{t-1}+\varepsilon_{g t}$, with $\left|\rho_{g}\right|<1$, and $\varepsilon_{g t} \sim i i d\left(0, \sigma_{g}\right) .^{7}$ Shocks to government expenditure serves as a second source of uncertainty in the model.

The nominal money supply process is assumed to follow: ${ }^{8}$

$$
M_{t}^{s}=\mu_{t} M_{t-1}^{s}
$$

where $\log \mu_{t}=\rho_{\mu} \log \mu_{t-1}+\varepsilon_{\mu t}$, with $\left|\rho_{\mu}\right|<1$, and $\varepsilon_{\mu t} \sim i i d\left(0, \sigma_{\mu}\right)$. Shocks to the growth rate of the nominal money supply introduce a third source of uncertainty in the model.

The government finances its expenditures and lump sum transfers to the representative household through seignorage. It must satisfy its budget constraint, which is given by:

$$
P_{t+j} G_{t+j}+\Gamma_{t+j}=M_{t+j}^{s}-M_{t-1+j}^{s}
$$

for all $j=0,1, \ldots ., \infty$.

\footnotetext{
${ }^{7}$ This assumption simplifies adjusting the model to account for steady state growth.

${ }^{8}$ McGrattan (1999) shows that the response of real variables with respect to productivity and government spending shocks is affected by the choice of monetary policy rule. Since our main objective is to focus on the propagation mechanism of monetary shocks, we do not consider more general policy feedback rules in the benchmark economy. However, in Section 6, we evaluate our results under the case in which monetary policy is described by a Taylor Rule.
} 


\subsection{Market clearing}

Finally, the economy is subject to the following resource constraint:

$$
Y_{t+j}=C_{t+j}+I_{t+j}+G_{t+j}
$$

In the money market, the equilibrium quantity of nominal money demanded must equal supply:

$$
M_{t+j}^{d}=M_{t+j}^{s} .
$$

\subsection{Equilibrium}

An equilibrium for this economy is a collection of allocations for: consumers $\left\{C_{t}, e_{t}\right.$, $\left.N_{t+1}, U_{t}, K_{t+1}, M_{t}, B_{t+1}\right\}$; and producers $\left\{Y_{t}, K_{t}, N_{t}, e_{t}, U_{t}\right\}$; together with prices

$\left\{w_{t}, r_{t}, R_{t-1}, P_{t}\right.$ and $\widetilde{P}_{t}^{i}$ for $\left.i \in[0,1]\right\}$ that satisfy the following conditions: (a) taking prices as given, consumer allocations solve the consumer's problem, (b) taking all prices but their own as given, producer allocations satisfy the producer's problem, (c) factor markets clear, and (d) the resource constraint holds.

In order to investigate the dynamics of the model, we log-linearise the equilibrium conditions around the steady state. The system of log-linear equations is presented in Appendix 2.

\subsection{Shocks}

There are three types of shocks in this model: two real shocks (technology and government spending), and a nominal money supply shock. Each shock is assumed to follow an $\mathrm{AR}(1)$ process:

Productivity

$$
\hat{v}_{t}=\rho_{A} \hat{v}_{t-1}+\varepsilon_{A t}
$$

Government Spending

$$
\widehat{g}_{t}=\rho_{g} \widehat{g}_{t-1}+\varepsilon_{g t}
$$

Money

$$
\widehat{\mu}_{t}=\rho_{\mu} \widehat{\mu}_{t-1}+\varepsilon_{\mu t}
$$


where $\varepsilon_{A t}, \varepsilon_{g t}$, and $\varepsilon_{\mu t}$ are mutually independent white noise, normally distributed processes.

\section{Benchmark model}

\subsection{Calibration}

In this section we describe the parameter values for our benchmark economy.

\begin{tabular}{|c|c|c|}
\hline Parameter & Description & Value \\
\hline$\beta$ & Discount factor & $1.03^{-1 / 4}$ \\
\hline$\alpha$ & Elasticity of effective labour & 0.674 \\
\hline$\theta$ & Preference parameter for leisure & 3.89 \\
\hline$h$ & Shift length, in hours & 324.8 \\
\hline$\chi$ & Fixed cost of travel, in hours & 60 \\
\hline$\tau$ & Total time endowment in hours & 1369.2 \\
\hline$\gamma_{x}$ & Gross trend growth rate of technology & 1.0034 \\
\hline$\delta$ & Steady state rate of depreciation & 0.0195 \\
\hline$\phi$ & $\begin{array}{l}\text { Elasticity of depreciation with respect to } \\
\text { utilisation }\end{array}$ & 1.56 \\
\hline$\frac{\rho}{\rho-1}$ & Gross steady state mark-up & 1.145 \\
\hline $1 /\left(\varepsilon R^{S S}\right)$ & $\begin{array}{l}\text { Interest semi-elasticity of money } \\
\text { demand }\end{array}$ & 0.14 \\
\hline$\eta$ & $\begin{array}{l}\text { Probability that a firm will be unable to } \\
\text { change its price }\end{array}$ & 0.25 \\
\hline$e, U$ & $\begin{array}{l}\text { Steady state level of effort and capital } \\
\text { utilisation }\end{array}$ & $1.0,1.0$ \\
\hline$N$ & Steady state employment rate & 0.8 \\
\hline$\rho_{A}$ & $\mathrm{AR}(1)$ parameter on productivity shock & 0.0 \\
\hline$\rho_{\mu}$ & $\mathrm{AR}(1)$ parameter on money shock & 0.603 \\
\hline$\rho_{g}$ & $\begin{array}{l}\text { AR(1) parameter on government } \\
\text { spending shock }\end{array}$ & 0.956 \\
\hline$\sigma_{A}$ & $\begin{array}{l}\text { Standard deviation of technology } \\
\text { innovations }\end{array}$ & 0.0072 \\
\hline$\sigma_{\mu}$ & $\begin{array}{l}\text { Standard deviation of money } \\
\text { innovations }\end{array}$ & 0.0082 \\
\hline$\sigma_{g}$ & $\begin{array}{l}\text { Standard deviations of government } \\
\text { innovations }\end{array}$ & 0.0146 \\
\hline
\end{tabular}

For ease of comparability, most of the parameter values in our benchmark model correspond to those reported in Burnside and Eichenbaum (1996). ${ }^{9} \quad \beta, h, \chi, \tau, \rho$

\footnotetext{
${ }^{9}$ In addition to ease of comparability, this procedure is sensible given the low degree of nominal rigidity assumed in the benchmark case.
} 
and $\varepsilon$ are not estimated. The discount factor is calibrated such that the steady state annualised real interest rate is equal to $3 \%$. The parameter $h$, the number of hours worked by an employed person, is calibrated so that the steady state level of effort equals one. The time spent commuting per quarter, $\chi$, is set to $60 .{ }^{10}$ This value falls in the middle of the range reported by Burnside and Eichenbaum (1996). The total quarterly time endowment $\tau$ is fixed at 1,369.2 hours.

In the model, the indivisibility of labour assumption makes aggregation easier, and implies a within period employment elasticity of zero, in line with empirical estimates indicating that labour supply elasticities are quite small. The elasticity of effort supply, however, is given by $\frac{\tau-\chi-h e_{t}}{h e_{t}}$, which in steady state takes a value of approximately 3. Blanchard and Fischer (1989), Ball, Mankiw, and Romer (1988) and Blanchard (1990) note that although very elastic labour supply in a model of sticky prices can generate large nominal rigidities, actual labour supply elasticities have been estimated to be fairly small. In order to evaluate the impact of labourhoarding on the persistence properties of our model, Section 6 considers more general preferences that do not have these features.

The calibrated value for the parameter $\rho$ implies a steady-state markup of $14.5 \%$, and the interest semi-elasticity of money demand, $1 / \varepsilon \mathrm{R}^{\mathrm{ss}}$, is calibrated to take on a value of 0.14. This value is consistent with the values estimated in Stock and Watson (1993). 11,12

The parameters $\alpha, \theta, \gamma_{x}, \delta, \phi, \rho_{A}, \rho_{g}, \sigma_{A}$, and $\sigma_{g}$ take the estimated values given in Burnside and Eichenbaum (1996). The persistence $\rho_{\mu}$ and variance $\sigma_{\mu}$ of the monetary policy shock are taken from the estimation in Yun (1996).

\footnotetext{
${ }^{10}$ This amounts to commuting approximately 1 hour per day.

${ }^{11}$ The consumption elasticity of money demand equals $\sigma / \varepsilon$. In order to maintain comparability with

Burnside and Eichenbaum, we set $\sigma=1$ in the benchmark specification. However, our results hold for more plausible values of the consumption elasticity of money demand. Specifically, when

$\sigma=5$ (implying a consumption elasticity of 0.7 ), our results with respect to a monetary disturbance do not change.

${ }^{12}$ See also Mankiw and Summers (1986), and Lucas (1988).
} 
The remaining key parameter values of the model are $\phi$, the parameter governing the degree to which firms will choose to vary capital utilisation in response to shocks, and $\eta$ the degree of nominal rigidity. As discussed in Burnside and Eichenbaum (1996), the estimate of $\phi$ depends on the mean of the depreciation series $\delta$, which is estimated to take on a value of 0.0195 . Normalising the steady state rate of capital utilisation to 1 then implies that $\phi=1.56$.

In standard sticky-price models, $\eta$ often takes the value of around 0.75 , indicating that firms change their price on average once a year. Estimates of this parameter vary from 0.75 in Gali and Gertler (1999), to 0.5 in Gali, Gertler, Lopez-Salido (2001). ${ }^{13}$ Our benchmark value of $\eta=0.25$ assumes a lower degree of nominal rigidity. This is discussed further below.

\subsection{Impulse responses}

In this section we report the impulse response of the benchmark model to a productivity, government spending, and money shock.

Figure 1 plots the responses of the endogenous variables to a $1 \%$ i.i.d. shock to productivity growth. Because the assumed degree of nominal rigidity is very low in the benchmark model (the average frequency of price adjustment is a little over once per quarter), the impulse responses reported here essentially replicate those in Burnside and Eichenbaum (1996). The key finding of that paper is that variable factor utilisation magnifies the impact of a real shock. In addition, despite the fact that productivity growth shocks are assumed to be white noise, the real effect of the shock is highly persistent. This is because both labour and capital services can vary immediately in response to shocks. Firms would like to increase their factor inputs to fully exploit the temporarily higher growth rate of productivity. In a standard twofactor input model with predetermined capital, the increased demand for labour services is dampened somewhat by the short-run rigidity of capital, which causes the marginal productivity of labour to decline quite sharply. With variable factor utilisation, firms can increase capital as well as labour services. In doing so, their action magnifies the impact effect of the productivity shock on output.

\footnotetext{
${ }^{13}$ See Blinder (1994), Sbordone (1998) for empirical evidence of nominal price rigidities in the US.
} 
The effect of the shock is persistent because of the combined effect of utilisation on depreciation and hence the capital stock, and the assumption of labour hoarding. In periods following the shock, the physical capital stock is relatively low. Output must remain high to finance investment and build up the capital stock. Utilisation and employment remain above steady state to generate the higher output needed to bring the capital stock up to its new steady state. The transition path of the capital stock to its new steady state is relatively slow, however, since higher utilisation rates along this path dampen the rate at which capital accumulates. In addition to this mechanism, the assumption that it is costless to adjust employment in the period after the shock leads to an immediate response of effort in the impact period. In the period following the shock, employment responds by relatively more, leading to a humpshaped response in output.

Figure 2 plots the model impulse responses to a temporary increase in the growth rate of government spending. The effect of a demand shock is also similar to that found in Burnside and Eichenbaum's original model. Utilisation and effort increase on impact to satisfy temporarily higher demand. Higher utilisation in turn temporarily reduces the capital stock. Output remains high in subsequent periods, reflected in utilisation and employment rates above steady state, to satisfy the temporarily higher demand and finance investment in order to restore the capital stock to it steady state level.

Figure 3 plots the impulse responses to a shock to the money supply. Despite the low degree of nominal rigidity assumed, the response of the real variables to the shock is on par with the effect of real shocks on the economy. The increase in output is driven by a surge in investment, with consumption remaining relatively flat. ${ }^{14}$ In the impact period of the shock, output increases by almost the same amount as effort. Since the rise in capital utilisation is associated with additional costs in the form of depreciation, while the rise in effort is not, the marginal product of effective capital rises by more than the marginal product of effective labour. The surge in investment is in response to the increased marginal productivity of effective capital.

Real marginal costs increase on impact, but by only $1 / 3$ of the change in output. This is due to the assumption of capital hoarding. Since firms hoard capital in equilibrium,

\footnotetext{
${ }^{14}$ Christiano, Eichenbaum and Evans (2001) are able to dampen the response of investment and increase the response of consumption by introducing investment adjustment costs.
} 
the marginal benefits of an increase in utilization on output are larger than the marginal costs.

The effect of the shock is quite persistent in subsequent periods, with variables returning to steady state in approximately five quarters-somewhat longer than the period over which prices are assumed to be fixed at just over one quarter. The humpshaped response in output arises for the same reason as in the case of a productivity shock: employment in the period after the shock rises by more than the contemporaneous response of effort.

The persistent output response is in contrast with the immediate price level response. Prices react quickly to a monetary shock, mainly reflecting the large proportion $(75 \%)$ of firms that are allowed to reset their price each period and also because of the effect of the monetary shock on future inflation. Given the positive slope of the real marginal costs curve, when a firm gets a signal it will adjust its price by a higher percentage than the change in the money supply.

The nominal interest rate increases in response to a monetary expansion. The model is therefore unable to generate a liquidity effect. This is a common feature of sticky price models of the business cycle and is due to the increase of expected inflation after a monetary shock. Expected inflation is high because a positive shock to the money supply increases the long run price level, whereas prices cannot adjust in the short run. Finally the movements in expected inflation and nominal interest rates leave the real interest rate fairly unaffected.

\section{$4 \quad$ Other sticky-price models}

This section considers alternative sticky-price models with the aim of comparing our benchmark model with time-varying factor utilisation to models without capital, and models with capital and capital adjustment costs.

We first consider a model with no capital. Such a model has a similar structure to the one presented above, but with a fixed level of capital services and employment, where variations in effort are now interpreted as variations in labour supply. 
We also consider a standard two-factor input model. ${ }^{15}$ This corresponds to our model of time-varying factor utilisation under the condition of constant capital utilisation and employment, so that variations in the capital stock and effort are now simply interpreted as variations in capital and labour. Standard two-factor input models with endogenous capital typically introduce capital adjustment costs in order to reduce the response of real variables to a money shock (see King and Watson, 1996, Chari, Kehoe and McGrattan, 2000, and Casares and McCallum 2000, Woodford 2000). To facilitate comparison purposes across the different capital adjustment costs found in the literature, we adopt a simple quadratic specification that takes the form:

$$
I_{t+j}=K_{t+1+j}-(1-\delta) K_{t+j}+\frac{b}{2}\left[\frac{K_{t+1+j}-(1-\delta) K_{t+j}}{K_{t+j}}-\left(\gamma_{x}-1+\delta\right)\right]^{2} K_{t+j}
$$

where the parameter $b$ determines the size of the capital adjustment cost. As owners and suppliers of the capital stock, these adjustment costs are borne by the household.

In the standard one- and two-factor input model, effort is interpreted as labour supply. ${ }^{16}$ As is common in the literature, its steady state value is calibrated to $1 / 3$. The adjustment cost parameter, $b$, takes on a value of 19.4, and governs the response of investment to changes in the real return of the asset. ${ }^{17}$ When there are no capital adjustment costs $(b=0)$, then the response of investment is unconstrained, and in the case of money shocks leads to unrealistically large responses in investment and output. $^{18}$ For this reason, the parameter indexing the size of adjustment costs is a crucial parameter governing the response of sticky-price models with capital. Our benchmark value for $b$ is calibrated in a similar way to that in Casares and McCallum

${ }^{15}$ The calibrated parameter values for the model variants are reported in Table 2 in the appendix. Only parameter values that take on a different value from those reported in Table 1 are included below.

${ }^{16}$ In this case, the elasticity of labour supply is given by $\frac{1-e_{t}}{e_{t}}$, which for our calibration implies a steady state value of around 2, somewhat lower than the typical value assumed in the RBC literature. ${ }^{17}$ If adjustment costs are described generically by the function $\phi\left(\frac{I_{t}}{K_{t}}\right)$, where $1 / \phi^{\prime}\left(\frac{I_{t}}{K_{t}}\right)$ is interpreted as Tobin's $q$, then adjustment costs affect the second derivative $\phi^{\prime \prime}\left(\frac{I_{t}}{K_{t}}\right)$. When adjustment costs are zero, the second derivative is zero. The higher the adjustment cost parameter $b$, the larger the second derivative, and the smaller the response of the investment-to-capital ratio to variations in Tobin's $q$.

${ }^{18}$ See Casares and McCallum (2000) and Ellison and Scott (2001). 
(2000), namely that the semi-elasticity of investment with respect to the return premium on the real asset is around $3.25 \%$. The resulting value for the adjustment cost parameter falls within the wide range of values consistent with the parameterisation criteria in the above references. These are given in Table 3.

\begin{tabular}{|c|c|c|}
\hline \multicolumn{3}{|c|}{ Table 3: Capital Adjustment Cost Parameter, $b$} \\
\hline Woodford, (2000) & 3 & $\begin{array}{l}\text { Calibrated such that the degree of } \\
\text { responsiveness of private expenditure is } \\
\text { similar to that estimated in Rotemberg } \\
\text { and Woodford (1997). }\end{array}$ \\
\hline $\begin{array}{l}\text { Casares and } \\
\text { McCallum, (2000) }\end{array}$ & $13.4-19.4$ & $\begin{array}{l}\text { Calibrated such that the semi-elasticity of } \\
\text { investment with respect to the return } \\
\text { premium on the real asset is } 2.25-3.25 \% \text {. }\end{array}$ \\
\hline $\begin{array}{l}\text { King and Watson, } \\
\text { (1996) }\end{array}$ & 40 & $\begin{array}{l}\text { Calibrated such that the elasticity of the } \\
\text { investment-to-capital ratio with respect to } \\
\text { Tobin's } q \text { is } 1 .{ }^{19}\end{array}$ \\
\hline $\begin{array}{l}\text { Chari, Kehoe, and } \\
\text { McGrattan, (2000) }\end{array}$ & $87,88.5,110$ & Calibrated such that $\sigma(I) / \sigma(Y) \cong 3.25$. \\
\hline
\end{tabular}

\subsection{Comparison of impulse responses}

In this section we compare the impulse responses of our benchmark model of timevarying factor utilisation to those of other sticky-price models. ${ }^{20}$ The degree of nominal rigidity assumed implies firms adjust their price on average just over once per quarter $(\eta=0.25)$.

Figure 4 illustrates the basic motivation behind Burnside and Eichenbaum's model, namely that standard models with constant utilisation rates cannot generate a persistent response to i.i.d. productivity growth shocks. The impact effect of the shock, as well as the persistence, is much lower in models without time-varying factor utilisation. In order to generate persistence, a highly autocorrelated productivity shock in levels (eg $\rho_{A}=0.95$ ) is typically assumed in these models.

We now turn to the various model responses to a money shock. These are illustrated in Figure 5.

\footnotetext{
${ }^{19}$ The estimated parameter assumes quadratic adjustment costs as described by Eq. 1.23.

${ }^{20}$ For brevity we only compare the model responses to productivity and money shocks.
} 
In models with constant factor utilisation, the low degree of nominal rigidity is reflected in a very small response of real variables. For reasons discussed above, however, our benchmark sticky-price model with factor utilisation has a relatively large impact and persistent response to a money shock.

An interesting feature of Figure 5 is the implied relationship between output, real marginal cost and nominal variables across the different models. The response of real marginal costs, inflation and nominal interest rates is coincident across models, whereas the response of output and real interest rates is quite different. Although real marginal costs rise by the same amount in response to a monetary policy expansion, the output response under factor utilisation is three times larger than in sticky price models with capital adjustment costs and no capital. Woodford (2000) finds similar cyclical variation in real marginal costs for standard models both with and without capital, which he attributes to relatively small cyclical variation in the capital stock. ${ }^{21}$ A thorough look at the impulse responses of the factor inputs in Figure 5 reveals that in all the models labour moves almost one-to-one with output. However, this is not true for the movements in investment. In the standard sticky price model with capital adjustment costs, investment moves one-for-one with output and labour, whereas in the factor hoarding model, the reaction of investment is four times larger than the reaction of output and labour, and in the sticky price model with no capital adjustment costs it is three times larger. The different responses of investment across the different models also explains the different behaviour of real interest rates. On the other hand, the similarities in the reaction of the real marginal costs explain the similarities in the reaction of the nominal variables across the different model specifications. Since inflation is mainly determined by the path of real marginal costs, the behaviour of actual and expected inflation across the models is also similar.

\section{$5 \quad$ Model simulations}

\subsection{Model statistics}

In this section we investigate simulated statistics in order to assess the performance of the factor utilisation model relative to the data as well as across the different model variants. $^{22}$ We allow for both productivity and nominal and real policy shocks, the

\footnotetext{
${ }^{21}$ This relation is further discussed in Section 5.2.

${ }^{22}$ Each simulation is made up of 500 observations, and is repeated 500 times. The reported sample statistics represent averages across simulation experiments.
} 
standard deviations of which are calibrated as reported in Table 1. In Table 4 we first compare model statistics across the sticky-price model variants assuming our benchmark low degree of nominal rigidity. The relatively low standard deviations for output in the no capital, capital, and capital with adjustment costs cases reflect the limited amount of response in those models to both white noise productivity growth shocks and money shocks in an environment of low nominal rigidity. ${ }^{23}$ The statistics of the factor utilisation model match the data better. Despite the absence of capital adjustment costs, investment does not vary too much, but by more than in a standard sticky-price model with capital. The increased variability of investment is a consequence of the depreciation-through-use assumption and the desire by firms to invest such that the capital stock comes on line with employment. As in Burnside, Eichenbaum, and Rebelo (1993), the standard deviation of effort accounts for approximately $1 / 5$ of the standard deviation of effective labour supply. By contrast, the standard deviation of capital services is dominated by the standard deviation in utilisation, estimated at $2.22 \%$.

When we consider conditional moments, we find that all shocks have a substantial role in explaining the variance of the real variables for the factor utilisation model. In particular, $56 \%$ of the variability of output is due to productivity shocks, while $27 \%$ is due to monetary shocks. Real supply and real demand shocks account for $61 \%$ of the variability of investment and the remaining $39 \%$ is due to monetary shocks. By comparison, in the no capital model, most of the variability of the real variables is due to real shocks and monetary shocks have a very small overall effect. This is in accordance with models with capital where fluctuations in real variables are dominated by supply shocks when the assumed degree of nominal rigidity is fairly low. In particular, $72 \%$ of the fluctuations in output are due to productivity shocks, while money shocks account for only $14 \%$ of these fluctuations. In the model with capital adjustment costs, these values become $71 \%$ and $9 \%$, respectively. Again, money has a relatively small role on explaining business cycle fluctuations because the degree of nominal rigidity assumed is very low.

\footnotetext{
${ }^{23}$ The statistics reported here for the model variants do not reflect the better fit of real business cycle models, such as the indivisible labour model of Hansen (1985). 
Table 4: Model Statistics, $\eta=0.25$

\begin{tabular}{|c|c|c|c|c|c|}
\hline & & \multicolumn{4}{|c|}{ Model Setting } \\
\hline & Data* & No capital & Capital & $\begin{array}{l}\text { Capital with } \\
\text { adjustment } \\
\text { costs }\end{array}$ & $\begin{array}{c}\text { Time-varying } \\
\text { factor } \\
\text { utilisation } \\
\end{array}$ \\
\hline$\sigma(Y)$ & 1.72 & 0.73 & 0.78 & 0.71 & 1.54 \\
\hline$\sigma(C)$ & 0.86 & 0.88 & 0.49 & 0.58 & 0.67 \\
\hline$\sigma(I)$ & 8.24 & - & 1.50 & 0.88 & 4.32 \\
\hline$\sigma(e)$ & - & 0.73 & 0.95 & 0.75 & 0.49 \\
\hline$\sigma(e N)$ & 1.59 & - & - & - & 2.10 \\
\hline$\sigma(K)$ & $0.63^{* * *}$ & - & 0.92 & 0.92 & 0.89 \\
\hline$\sigma(K U)$ & - & - & - & - & 1.29 \\
\hline$\sigma(R)$ & 1.29 & 2.31 & 2.32 & 2.20 & 2.38 \\
\hline
\end{tabular}

*Data for the US are taken from Cooley (1995), Ch. 7, Table 7.1.

**Bils and Cho (1994), HP filtered quarterly US data, 1955:3-1984:1

Model statistics are calculated numerically from model simulations.

We now look at the model statistics in the case where the degree of nominal rigidity is assumed to take on a more standard value of $\eta=0.75$. These are reported in Table 5 . The statistics indicate that the no capital model matches the data fairly well. The main problem is that consumption is too volatile. This could be reduced with the introduction of habit formation in household preferences (see Fuhrer, 2000). The model with capital illustrates the excessively volatile response of investment and hence output when there are no capital adjustment costs. The increase in labour required to meet the unexpected increase in demand raises the marginal productivity of capital and leads to a surge in investment. In order to dampen this response, capital adjustment costs are typically introduced.

The model with capital and adjustment costs is considered as an intermediate case: the smaller the capital adjustment costs, the closer the model is to a standard two-factor input model; the larger the capital adjustment costs, the closer the model is to behaving as though capital were fixed. The statistics are somewhat similar to those reported in King and Watson (1996) for standard sticky price models. The simulations indicate that appropriate calibration of the capital adjustment cost parameters clearly has important implications for the behaviour of the model as noted by Woodford (2000). 
Comparing the last two columns illustrates that introducing factor utilisation exacerbates the volatility of investment and hence output. This is because firms can now meet the increase in demand not just through higher labour inputs, but higher capital utilisation as well. This raises the marginal productivity of physical capital even more, leading to an even greater surge in investment than in the standard twofactor input model with no capital adjustment costs. The introduction of factor utilisation, therefore, worsens the dynamic properties of the model by increasing the sensitivity of investment with respect to monetary shocks. But it is precisely the increased sensitivity of investment that allows for a reduction in the degree of nominal rigidity in a model with time-varying factor utilisation, without sacrificing its response to policy shocks.

This point is better illustrated by considering the conditional moments of the shocks. In the factor hoarding model with a high degree of nominal rigidity (and also in the model with capital and no adjustment costs), the magnitude of the response of real variables with respect to monetary shocks is huge. As a result, monetary shocks are the dominant source of fluctuations in real variables in this case. For example, monetary shocks account for $86 \%$ of the fluctuations in output, while productivity disturbances account for just $11 \%$ of these fluctuations. Nominal shocks are the main source of fluctuations in the no capital model as well, although the absence of investment dynamics moderates the magnitude of the responses of real variables with respect to monetary disturbances in this case. 
Table 5: Model Statistics, $\eta=0.75$

\begin{tabular}{|l|c|c|c|c|c|}
\hline & & \multicolumn{4}{|c|}{ Model Setting } \\
\hline$\sigma(Y)$ & 1.72 & 1.26 & 4.03 & 1.63 & 16.65 \\
\hline$\sigma(C)$ & 0.86 & 1.82 & 0.51 & 1.37 & 1.07 \\
\hline$\sigma(I)$ & 8.24 & - & 16.09 & 3.19 & 66.63 \\
\hline$\sigma(e)$ & - & 1.86 & 6.74 & 2.76 & 11.79 \\
\hline$\sigma(e N)$ & 1.59 & - & - & - & 21.05 \\
\hline$\sigma(K)$ & $0.63^{* *}$ & - & 1.02 & 0.92 & 2.94 \\
\hline$\sigma(K U)$ & - & - & - & - & 13.26 \\
\hline$\sigma(R)$ & 1.29 & 1.36 & 2.49 & 1.21 & 2.86 \\
\hline
\end{tabular}

*Data for the US are taken from Cooley (1995), Ch. 7, Table 7.1.

**Bils and Cho (1994), HP filtered quarterly US data, 1955:3-1984:1

Model statistics are calculated numerically from model simulations.

Many authors have tried to evaluate empirically the importance of monetary versus real shocks in explaining business cycle fluctuations. Canova and De Nicolo (2000) find that the relative importance of the two disturbances varies across countries and over time, although their main finding is that nominal demand shocks are the dominant source of fluctuations in real variables for six of the G-7 countries. Roberts (1993) and Faust (1998) also find that monetary shocks have an important role for output variability in the US. On the other hand, Blanchard and Quah (1989), Temin (1998), King, Plosser, Stock and Watson (1991), and Astley and Yates (1999) provide empirical evidence that real disturbances are the main source of business cycle fluctuations. ${ }^{24}$

Given the mixed evidence on the sources of business cycles fluctuations, it is not possible to evaluate whether the factor hoarding model or the standard sticky price model is more relevant on the basis of conditional moments.

\footnotetext{
${ }^{24}$ Blanchard and Quah (1989) and Gali (1992), (1999) identify supply shocks that have permanent level effects, as assumed in our theoretical framework.
} 


\subsection{Output and real marginal cost}

To investigate further the question of persistence in response to a money shock, we estimate the elasticity of real marginal cost with respect to output. These are reported in Table 6, and reflect the findings of the impulse response functions, namely that although the behaviour of output differs across the model specifications in response to a money shock, the behaviour of real marginal cost is essentially identical. The results in Table 6 are perhaps not surprising, given that the relationship between marginal cost and output is affected by the behaviour of capital. The diverse response of capital across the various model specifications in turn accounts for the range of elasticity estimates.

Table 6: Elasticity of Real Marginal Cost with Respect to Output

\begin{tabular}{|l|l|l|l|l|}
\hline & \multicolumn{4}{|c|}{ Model Setting } \\
\hline Models & No capital & Capital & $\begin{array}{l}\text { Capital with } \\
\text { adjustment } \\
\text { costs }\end{array}$ & $\begin{array}{l}\text { Time-varying } \\
\text { factor } \\
\text { utilisation }\end{array}$ \\
\hline$\frac{\partial m c}{\partial y} \frac{y}{m c}$ & 2.97 & 1.23 & 2.07 & 0.24 \\
\hline
\end{tabular}

The relationship between marginal cost and output is crucial for understanding the model's response to monetary shocks. In principle, money has real effects only if firms react to unanticipated shifts in demand by increasing quantities rather than by increasing prices. Firms might behave so for two reasons: either because they are constrained from changing their price in the short-run (which in the sticky price models considered here depends on $\eta$ ), or because marginal cost is relatively flat in the short-run. In the latter case, firms have less of an incentive to raise their price in response to a demand shock since they are able to raise their output to satisfy demand without eroding their mark-up. An additional implication of the reduced sensitivity of marginal cost to output in a model of factor hoarding, therefore, is that it provides a potential mechanism by which nominal rigidities arise endogenously.

In a recent paper, Kiley (1998) shows that the assumption of partial price adjustment pricing, such as in the Calvo model we adopt here, imparts in general much more persistence than does Taylor-type staggered price setting. However, in the case where 
the elasticity of marginal cost with respect to output is small (eg less than one), the implications of the two types of price setting are equivalent. Our finding that marginal cost is relatively insensitive to changes in output suggests that the persistent output response to a monetary shock with relatively low price rigidity and timevarying factor utilisation holds more generally in staggered price setting models. This finding differs from that of Chari, Kehoe and McGrattan (2000), who conclude that output persistence cannot be rationalised within a standard business cycle model with staggered price setting without appealing to implausibly large nominal rigidities. In a model with factor utilisation, it seems, small degrees of nominal rigidity can lead to real and persistent response of output by flattening the marginal cost curve.

\subsection{Persistence}

We estimate the conditional autocorrelation coefficient, $\xi$, of the simulated output response to money shocks in order to evaluate the persistence of each of the model variants. The values of $\xi$ are reported in Table 7 . The greater the autocorrelation coefficient, the more persistent is the response of output.

Table 7 shows that the introduction of variable capital utilisation and effort in a sticky-price model increases the persistence of output relative to standard models despite the low degree of nominal rigidity assumed. This is because of the effect of utilisation on depreciation, and of labour hoarding. Labour hoarding prolongs the response of effective labour input, which in turn propagates the response of real variables. On the contrary, models with capital generate less persistence for a low degree of price stickiness. This reflects a lack of strong propagation mechanism in one and two- factor input models. The results in Table 7 are also consistent with the findings of Chari, Kehoe and McGrattan (2000), namely that the introduction of capital in a model where nominal rigidities provide another source of propagation reduces persistence by providing agents with a mechanism for smoothing unanticipated nominal shocks over time. 
Table 7: Autocorrelation

\begin{tabular}{|l|c|c|}
\hline Model Setting & $\begin{array}{c}\text { Autocorrelation } \\
\text { coefficient } \xi,(\eta=0.25)\end{array}$ & $\begin{array}{l}\text { Autocorrelation } \\
\text { coefficient } \xi,(\eta=0.75)\end{array}$ \\
\hline No capital & 0.52 & 0.75 \\
& $(0.0493)$ & $0.0382)$ \\
\hline Capital & 0.48 & 0.48 \\
& $(0.0506)$ & $0.0506)$ \\
\hline Capital with Adjustment Costs & 0.50 & 0.73 \\
& $(0.0499)$ & $(0.0399)$ \\
\hline Time Varying Factor Utilisation & 0.76 & 0.75 \\
& $(0.0378)$ & $(0.0380)$ \\
\hline Time Varying Factor Utilization ${ }^{+}-$standard & 0.75 & 0.74 \\
preferences & $(0.022)$ & $(0.022)$ \\
\hline Variable Capital Utilisation & 0.46 & 0.47 \\
& $(0.0513)$ & $(0.0508)$ \\
\hline Variable Effort & 0.72 & 0.72 \\
& $(0.0403)$ & $(0.0400)$ \\
\hline
\end{tabular}

* Numbers in the parenthesis denote standard errors.

+ For $\sigma_{n}=3, \sigma_{e}=8$, the results are robust to the values of elasticities used as long as $\sigma_{e} \gg \sigma_{n}$.

\section{Robustness}

In this section we investigate how much each of the various features of the timevarying factor utilisation model contribute to its performance.

\subsection{General Preferences}

In the benchmark model, preferences are such that the effort supply elasticity is large and time-varying. One could argue that the persistent effects of monetary shocks are a consequence of this particular utility specification. In this section we consider a more general specification of preferences with a smaller and constant elasticity of labour supply. The preferences we consider take the form:

$$
u\left(c_{t}, N_{t}, e_{t}, M_{t} / P_{t}\right)=\log C_{t}-\lambda_{n} \frac{1}{1+\sigma_{n}} N_{t}^{1+\sigma_{n}}-\lambda_{e} \frac{1}{1+\sigma_{e}} e_{t}^{1+\sigma_{e}}+\frac{\gamma}{1-\varepsilon}\left(\frac{M_{t}}{P_{t}}\right)^{1-\varepsilon}
$$

We find that under factor hoarding monetary shocks can still generate real and persistent effects on output even for this more general specification of preferences. In Table 7 we report the value of $\xi$ for the model of factor utilisation with the more general preference specification. On the basis of this, we conclude that the persistence 
results in a model of factor hoarding are robust to alternative preference specifications, and are not due to the indivisible labour supply assumption. As we have seen in the benchmark factor utilisation model, an unanticipated shock invokes changes in effort in the impact period, because of labour hoarding. In order to generate a hump-shaped response of effective labour, employment needs to increase by more in the second period than the impact response of effort. In the specification of Eq (1.24), this happens when the effort supply elasticity is lower than the employment supply elasticity $\left(\frac{1}{\sigma_{e}}<<\frac{1}{\sigma_{n}}\right)^{25}$

\subsection{Variable Capital Utilisation}

This section investigates whether our results on persistence are driven by the assumption of capital utilisation. Thus, we consider a two-factor input model with variable capital utilisation. Such a model has a similar structure to the two-factor input model presented of Section 4 with the additional feature that capital utilisation is timevarying. The calibrated values for this model are therefore the same as those reported in Table 2, except that $\phi=1.56 .^{26}$

Our estimates indicate that variable capital utilisation alone cannot account for the persistent response of output to monetary shocks (see Table 7), although it does increase the impact effect of the response of real variables to unanticipated shocks compared to a two-factor input model without time-varying capital utilisation. It is still the case that we can generate realistic investment volatility without having to assume capital adjustment costs at relatively low degrees of nominal rigidity. On the basis of these results we conclude that in order to generate persistence of real variables with respect to nominal shocks, variable capital utilisation must be combined with 'real rigidities' such as labour hoarding or wage rigidities as in Christiano, Eichenbaum, and Evans (2001).

\subsection{Variable Labour Effort}

If we alternatively consider a model in which there is no capital utilisation, and effort is the only contemporaneously variable factor input, then the impact effect of a

\footnotetext{
${ }^{25} \mathrm{We}$ investigate the behaviour of the model over a range of parameter values, $1<\sigma_{N}, \sigma_{e}<10$.

${ }^{26}$ See appendix 3 for a complete description of the parameter values. 
monetary shock on real variables is persistent but relatively small at low degrees of nominal rigidity. The model we consider is similar to the one in Burnside, Eichenbaum and Rebelo (1993), and corresponds with our benchmark model of Section 2 with $\phi=10000$. An increase in the degree of nominal rigidity raises the impact effect of a nominal shock on real variables, but at the cost of unrealistic investment volatility given that there are no constraints on adjusting capital.

The above analysis suggests that both capital and labour hoarding are important for generating large impact as well as persistent responses of real variables to nominal shocks at low degrees of nominal rigidity.

\subsection{Endogenous Monetary Policy}

In the preceding discussion we have focussed our attentions on equilibria in which monetary policy is exogenous. However, the empirical literature has demonstrated that policy movements are largely due to reactions in the state of the economy. In this section, we analyse whether the persistence properties of our model change when the money supply rule of equation (1.16) is replaced by a Taylor (1993) interest rate rule that responds to changes in the state of the economy. Such a rule has been shown to match the behaviour of interest rates quite well. ${ }^{27}$ In its most generic form, this rule takes the form:

$$
R_{t}=b_{\pi} \pi_{t}+b_{y} y_{t}+\mu_{t}
$$

where $b_{\pi}=1.5$ and $b_{y}=0.5$, as in Taylor's (1993) original specification, and $\mu_{t}$ represents a policy shock as before.

Our findings can be summarised as follows. First, for a low degree of nominal rigidity, the benchmark model of time-varying factor utilisation generates more persistence in output than the other sticky price model variants we investigate. Second, the response of real variables following a real shock remains essentially unchanged relative to the responses under a money rule. McGrattan (1999) shows that the response of real variables to real shocks is affected by the policy rule specification. In our case, however, this is not the case when $\eta=0.25$. This is because for low degrees of nominal rigidity the systematic component of monetary

\footnotetext{
${ }^{27}$ See Clarida, Gali, Gertler $(1998,2000)$ for a recent empirical analysis of Taylor rules. 
policy has almost no effect on real variables and the economy behaves as if it had flexible prices when hit by real shocks.

\section{Conclusions}

Recent debate has focussed on the failure of standard general equilibrium sticky-price models to generate business cycle fluctuations unless an extreme degree of price stickiness is assumed. This paper investigates the propagation mechanism of monetary shocks in an otherwise standard general equilibrium sticky-price model, modified to incorporate factor hoarding in the form of variable capital utilisation rates and labour effort. In contrast to previous studies, we find that real and persistent effects of monetary shocks can be generated at a relatively low degree of nominal rigidity.

In addition, we show that our model can generate realistic variances of capital and investment without having to assume capital adjustment costs. Contrary to standard sticky-price models with capital, the introduction of capital in our framework does not reduce persistence in response to nominal shocks. Indeed, the increased sensitivity of investment allows for a reduction in the assumed degree of nominal rigidity without sacrificing the model's response to policy shocks.

Finally, we compare the predictions of our model with standard sticky-price models both with and without capital in order to gain insight in the relationship between nominal price rigidity and a firm's ability to adjust capital and labour services. The sensitivity of marginal cost to output is closely related to a firm's ability to adjust its inputs. A model of variable factor utilisation introduces an additional margin by which firms can respond to unanticipated shocks, reducing the effect of output on marginal cost. In other words, variable capital utilisation results in a flattening of the marginal cost schedule thereby introducing the possibility of endogenous price stickiness. On the other hand, standard sticky-price models both with and without capital are subject to increasing short-run marginal costs, which in turn dampens the response of output. The real effect of monetary shocks on output in such models is consequently weak, and can only be accomplished by assuming a relatively high degree of nominal rigidity. 
Although our model generates substantial persistence in output, it cannot generate persistence in inflation. Variable factor utilization breaks the link between variations in output and in real marginal costs, through movements in capital utilization. However, the behaviour of marginal costs does not change dramatically across the model variants considered here, and as a result the inflation dynamics do not change either. In order to generate persistent responses of inflation to changes in the money supply one has to incorporate an additional real rigidity in the model, such as real wage rigidities, as in Christiano Eichenbaum and Evans (2001). Real wage rigidities have the effect of delaying the response of real marginal cost to changes in output, and as a result introduce persistence in inflation. 


\section{References}

Astley, M. and Yates, T. (1999), "Inflation and real disequilibria", Bank of England Working Paper Series, no. 103.

Ball, Larry. (1994), "Credible disinflation with staggered prices setting", American Economic Review 84, pp.282-289.

Ball, Laurence, Gregory Mankiw, and David Romer. (1988), “The New Keynesian economics and the output-inflation tradeoff", Brookings Papers on Economic Activity, pp. $1-82$.

Ball, Lawrence and David Romer. (1990), "Real rigidities and the non-neutrality of money", Review of Economic Studies 57, pp. 183-203.

Bils, Mark and Jang-Ok Cho. (1994), "Cyclical factor utilisation”, Journal of Monetary Economics 33, pp. 319-354.

Blanchard, Olivier. (1990), "Why does money affect output? A survey", Handbook of Monetary Economics, vol. 2, Amsterdam: North Holland, pp. 779-835.

Blanchard, Olivier and Stanley Fischer. (1989), Lectures in Macroeconomics, Cambridge: MIT Press.

Blanchard, Olivier and Danny Quah. (1989), "The dynamic effects of aggregate demand and supply disturbances", American Economic Review, 79, pp. 654-673.

Blinder, Alan. (1994), "On sticky prices: academic theories meet the real world" in Monetary Policy, Mankiw (ed), University of Chicago Press.

Burnside, Craig and Martin Eichenbaum. (1996), "Factor-hoarding and the propagation of shocks", American Economic Review 86, no. 5, pp. 1154-74.

Burnside, Craig, Martin Eichenbaum and Sergio Rebelo. (1993), "Labor hoarding and the business cycle", Journal of Political Economy 101, pp.245-273.

Calvo, Guillermo. (1983), "Staggered pricing in a utility maximising framework", Journal of Monetary Economics 12, pp. 383-396.

Casares, Miguel and Bennett McCallum. (2000), “An optimizing IS-LM framework with endogenous investment”, NBER Working Paper Series, no. 7908.

Canova, Fabio and G. De Nicolo. (2000), "On the sources of business cycles in the G-7”, Universitat Pompeu Fabra Working Paper Series.

Chari, V.V., Patrick Kehoe and Ellen McGrattan. (2000), "Sticky-price models of the business cycle: can the contract multiplier solve the persistence problem?"

Econometrica 68, pp. 1151-79.

Christiano, Laurence, Martin Eichenbaum and Charles Evans. (1997), "Sticky price and limited participation models: a comparison", European Economic Review 41, pp. 1173-1200. 
Christiano, Laurence, Martin Eichenbaum and Charles Evans. (2001), "Nominal price rigidities and the dynamic effects of a shock to monetary policy", working paper, Northwestern University.

Clarida, Richard, Jordi Gali, and Mark Gertler. (1999), "The science of monetary policy: a New Keynesian perspective", Journal of Economic Literature 37, pp. 16611707.

Cogley, Timothy, and James Nason. (1995), "Output dynamics in real-business cycle models", American Economic Review 83, pp. 492-511.

Cook, David. (1999), "Real propagation of monetary shocks: dynamic complementarities and capital utilisation", Macroeconomic Dynamics 3, pp. 368-383.

Cooley, Thomas and Gary Hansen. (1995), "Money and the business cycle", in Frontiers of Business Cycle Research, T. Cooley (ed.), Princeton University Press.

Ellison, Martin and Andrew Scott. (2001), "Sticky-prices and volatile output", Bank of England Working Paper Series, no. 127.

Fagnart, Jean-Louise, Omar Licandro, and Franck Portier. (1999), "Firm heterogeneity, capacity utilisation, and the business cycle", Review of Economic Dynamics vol. 2, pp. 433-455.

Faust, John. (1998), "On the robustness of the identified VAR conclusions about money”, Carnegie-Rochester Conference Series on Public Policy 49, pp. 207-244.

Fuhrer, Jeffrey, (2000), "Habit formation in consumption and its implications for monetary policy models", American Economic Review 90, pp. 367-90.

Gali, Jordi. (1992), “Does the IS-LM model fit US postwar data?" Quarterly Journal of Economics CVII, pp. 708-738.

Gali, Jordi. (1999), "Technology, employment and the business cycle: do technology shocks explain aggregate fluctuations?" American Economic Review 89, pp. 249-271.

Gali, Jordi and Mark Gertler. (1999), "Inflation dynamics: a structural econometric analysis", Journal of Monetary Economics 44, pp.195-222.

Gali, Jordi, Mark Gertler, and J. David Lopez-Salido. (2001), "European inflation dynamics", forthcoming European Economic Review.

Greenwood, Jeremy, Zvi Hercowitz, and Gregory Huffman. (1988), "Investment, capacity utilization, and the real business cycle", American Economic Review 78, pp.402-17.

Hansen, Gary. (1985), "Indivisible labour and the business cycle", Journal of Monetary Economics 16, pp. 309-28.

Jeanne, Olivier (1997), “Generating real persistent effects of monetary shocks: how much rigidity do we really need?' NBER Working Paper Series, no. 6258. 
Kiley, Michael. (1998), "Partial adjustment and staggered price setting", mimeo, Federal Reserve Board.

King, Robert, Charles Plosser, James Stock and Mark Watson. (1991), "Stochastic trends and economic fluctuations", American Economic Review 81, pp.819-40.

King, Robert and Mark Watson. (1996), "Money, prices, and interest rates and the business cycle", Review of Economics and Statistics 78, pp. 35-53.

King, Robert and Alex Wolman. (1996), "Inflation targeting in a St. Louis model of the $21^{\text {st }}$ century", Federal Reserve Bank of St. Louis Review.

Lucas Robert (1988). "Money demand in the US: a quantitative review", Carnegie Rochester Series on Public Policy 29, pp. 137-167.

Mankiw, Gregory, (2000), "The inexorable and mysterious trade-off between inflation and unemployment", NBER Working Paper Series, no. 7884.

Mankiw, Gregory and Ricardo Reis. (2001), "Sticky information vs sticky prices: a proposal to replace the New Keynesian Phillips curve", NBER Working Paper Series, no. 8290 .

Mankiw, Gregory and Lawrence Summers (1986). "Money Demand and the Effects of Fiscal Policy”, Journal of Money, Credit and Banking 18, pp. 415-429.

McCallum , Bennett. (1997), "Comment", in NBER Macroeconomics Annual, Bernanke and Gertler (eds). Cambridge, MA: MIT Press, pp. 355-359.

McCallum, Ben and Edward Nelson. (1999), "An optimising IS-LM specification for monetary policy and business cycle analysis", Journal of Money, Credit, and Banking, 31, pp. 296-316.

McGrattan, Ellen (1999). "Predicting the effects of Federal Reserve Policy in a sticky-price model: an analytical approach", Federal Reserve Bank of Minneapolis Working Paper Series, no. 598.

Roberts, John M. (1993), “The sources of business cycles: a monetarist interpretation", International Economic Review, 34, pp. 923-934.

Roberts, John M. (1995), "New Keynesian economics and the Phillips curve", Journal of Money, Credit, and Banking 27, pp. 975-984.

Rogerson, Richard. (1988), "Indivisible labour, lotteries and equilibrium", Journal of Monetary Economics, vol.21, no. 1, pp. 71-89.

Romer, David. (1996), Advanced Macroeconomics, New York: McGraw-Hill.

Rotemberg, Julio. (1987), "The New Keynesian microfoundations" in NBER Macroeconomics Annual, S. Fischer (ed.). Cambridge, MA: MIT Press, pp. 69-104.

Rotemberg, Julio and Michael Woodford. (1997), “An optimisation-based econometric framework for the evaluation of monetary policy", in B.S. Bernanke and 
J.J. Rotemberg (eds.), NBER Macroeconomics Annual 1997. Cambridge: MIT Press, pp.297-346.

Sbordone, Argia. (1998), "Price and unit labor cost: a new test of price rigidity", Institute for International Economic Studies, Stockholm University Seminar Paper, no. 653.

Stock, John and Mark Watson. (1993), "A simple estimator of cointegrating vectors in higher order integrated systems", Econometrica 61, pp. 783-820.

Taylor, John. (1979), "Staggered contracts in a macro model”, American Economic Review 69, pp.108-13.

Taylor, John. (1993), "Discretion versus policy rules in practise", CarnegieRochester Conference Series on Public Policy 39, pp. 195-214.

Temin, Peter. (1998), “The causes of American business cycles: an essay in economic historiography”, NBER Working Paper Series, no. 6692.

Woodford, Michael. (2000), "A neo-Wicksellian framework for the analysis of monetary policy" Chapter 4 of Interest and Prices, manuscript, Princeton University.

Yun, Tack. (1996), "Nominal price rigidity, money supply endogeneity, and business cycles”, Journal of Monetary Economics 37, pp. 345-370. 
Figure 1: Responses to a productivity shock
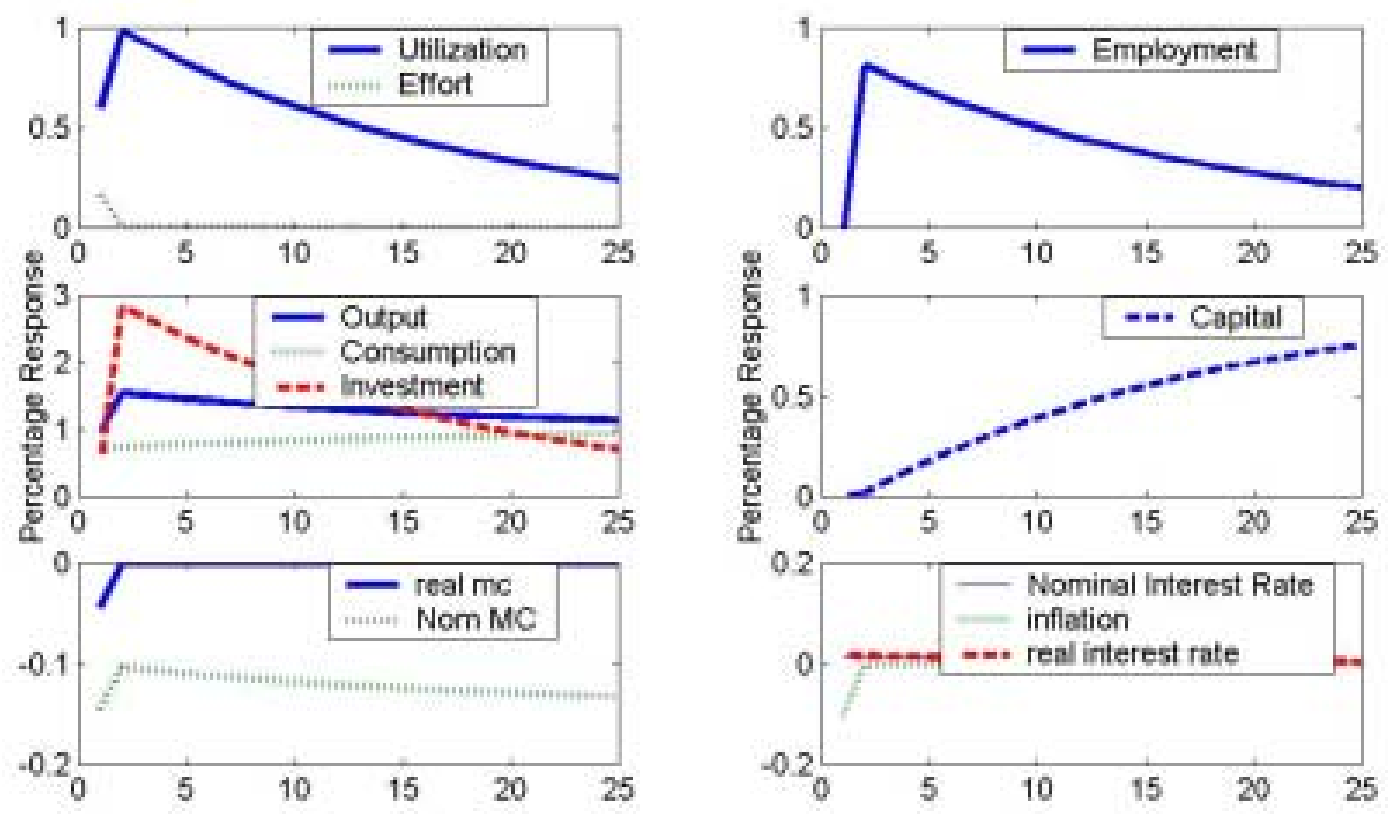
Figure 2: Responses to a government spending shock
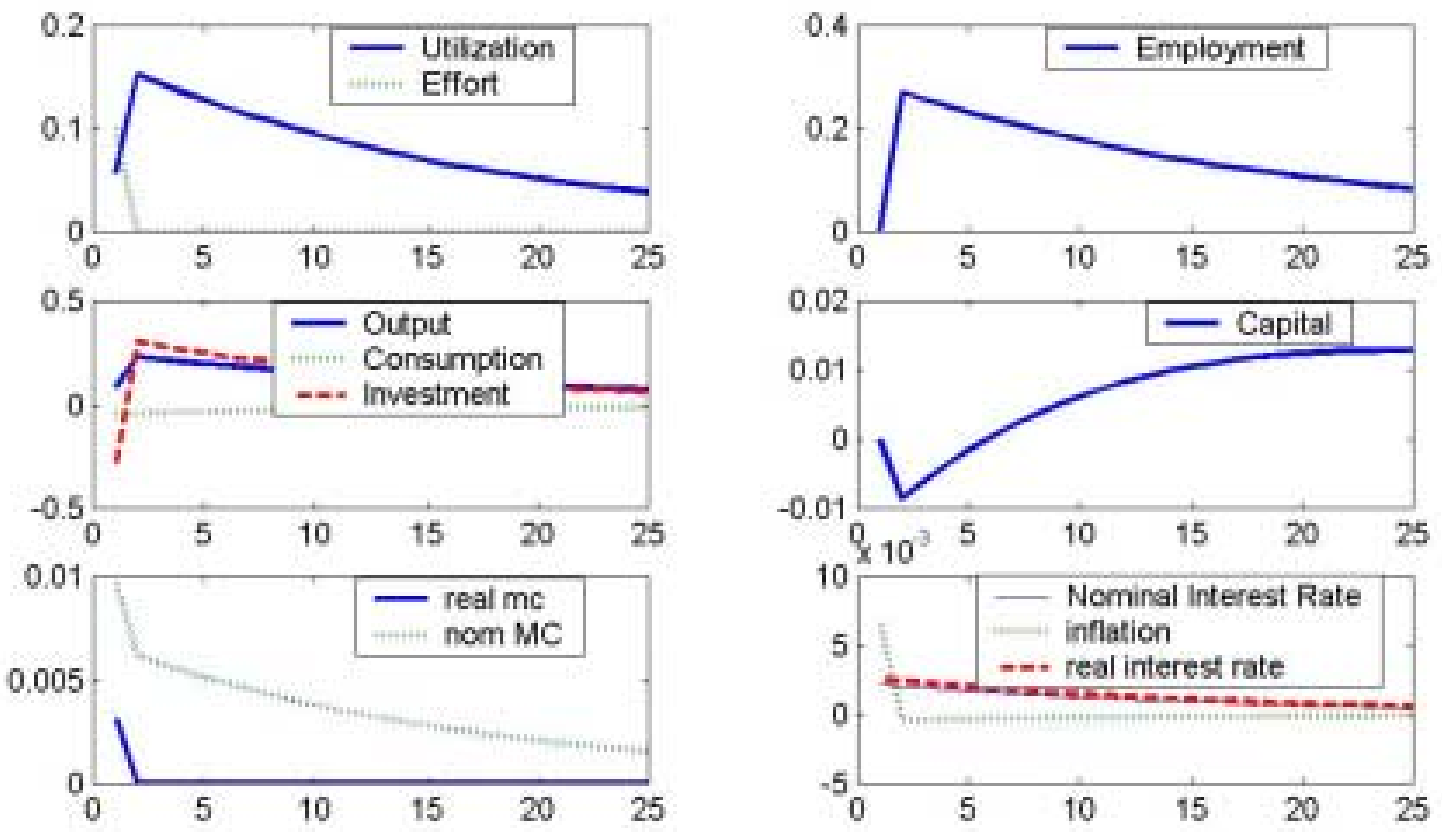
Figure 3: Responses to a money supply shock
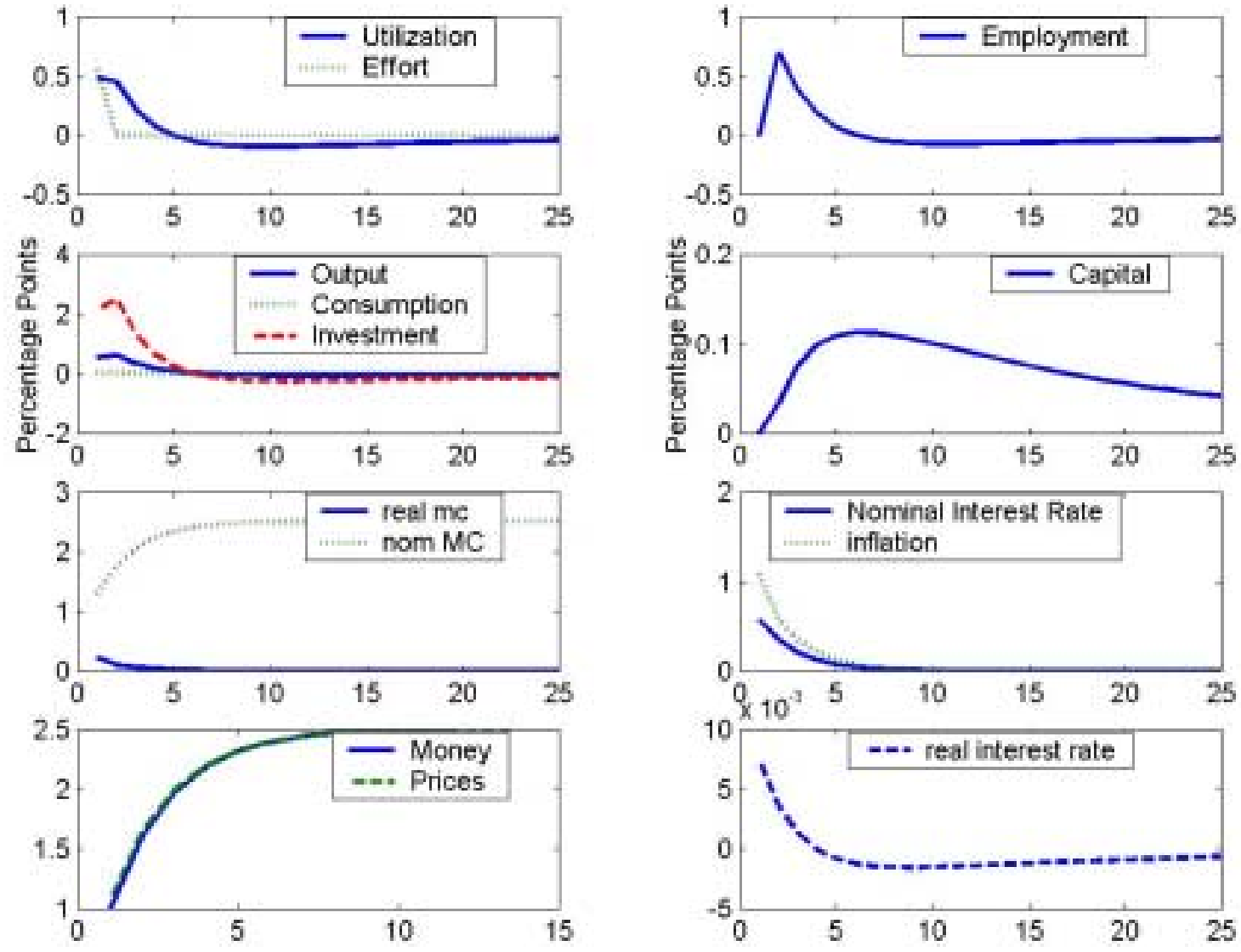
Figure 4: Response to a productivity shock

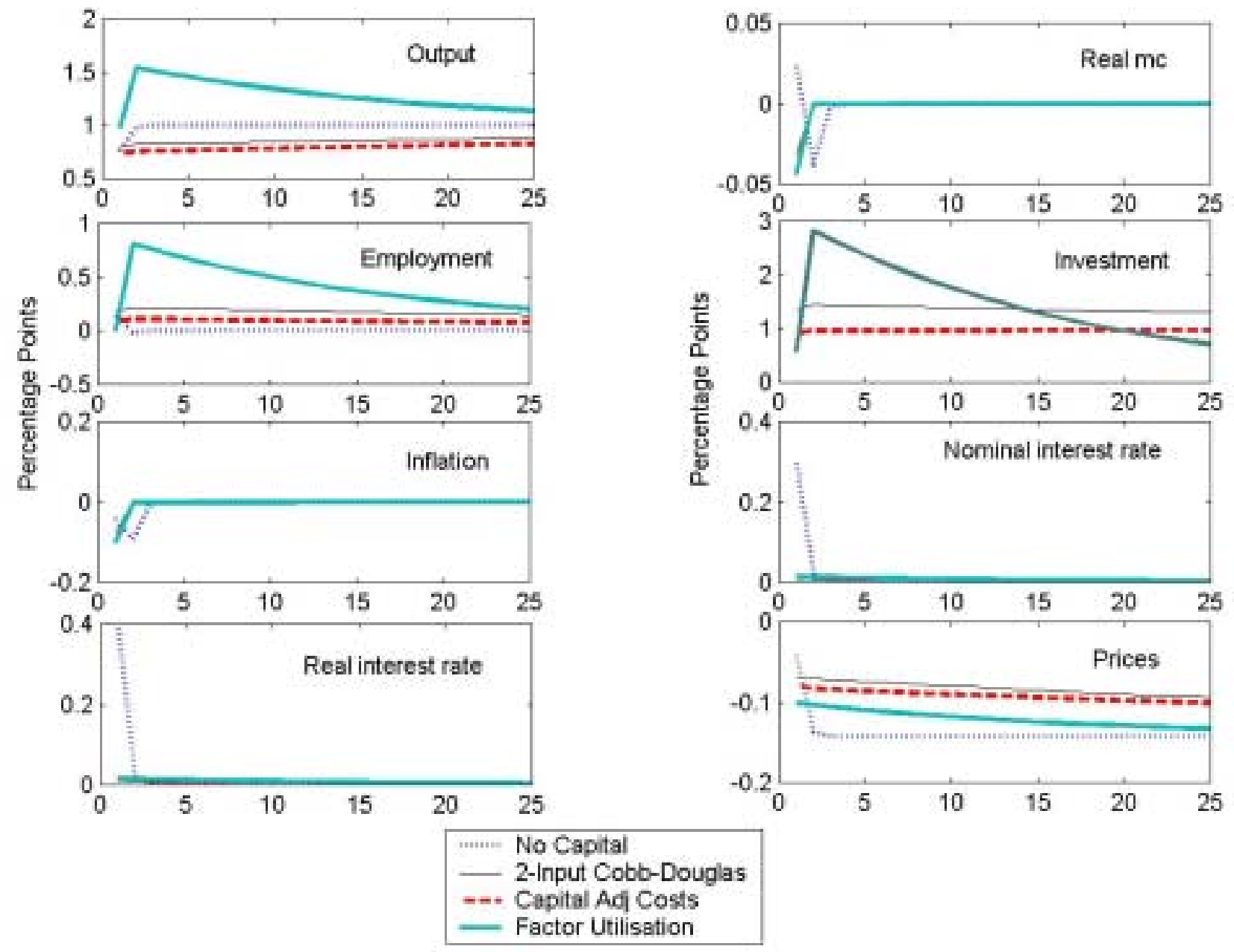


Figure 5: Response to a money supply shock
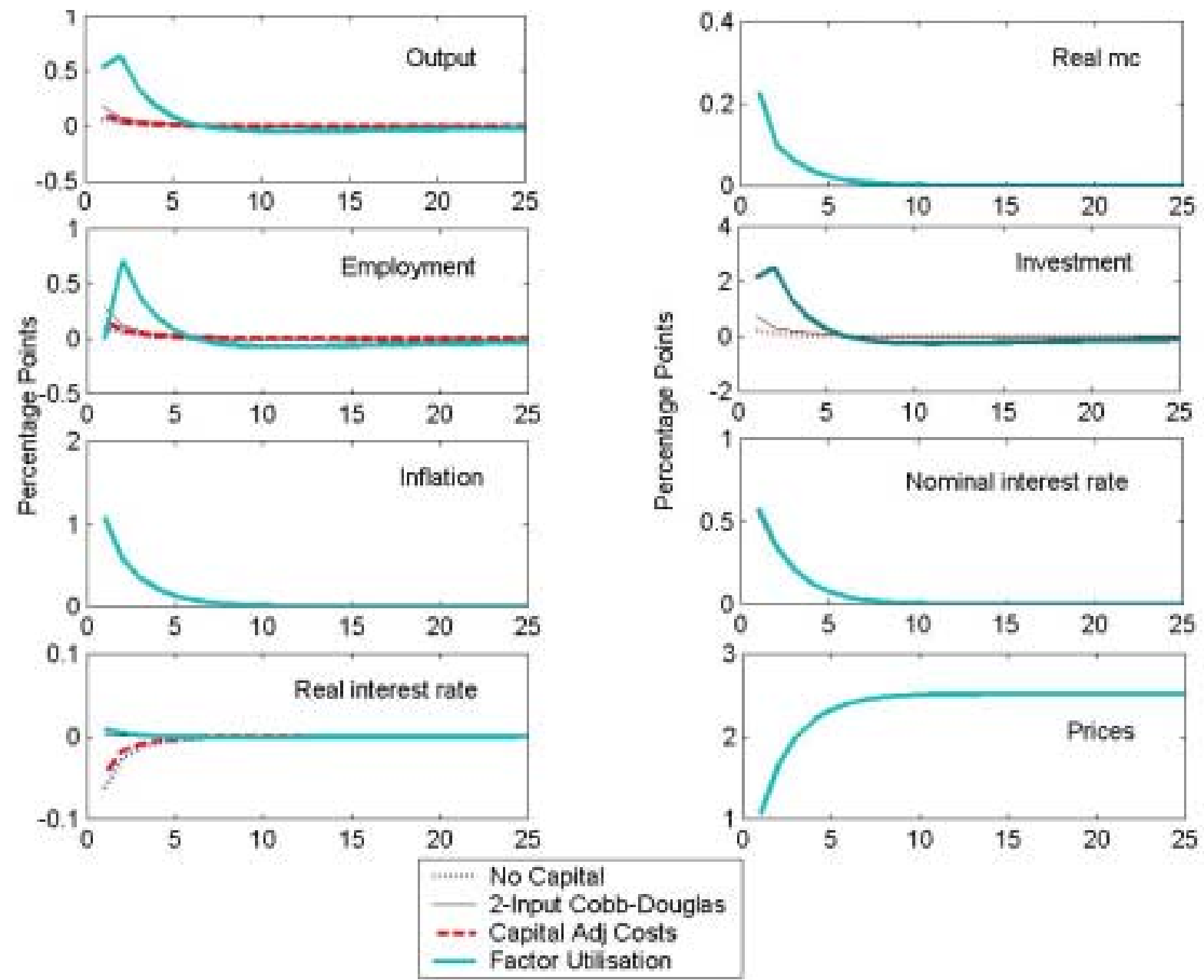


\section{Appendices}

These appendices collect the derivation of the equations used in the paper. They are included to facilitate the work of the referees but they are not intended for publication.

\section{Appendix 1: Representative household's first order conditions}

Allowing $\lambda_{t}$ to denote the Lagrange multiplier on the household's budget constraint, the first order conditions for the representative agent are given by:

Consumption

$$
\frac{1}{C_{t}}=P_{t} \lambda_{t}
$$

Money Demand

$$
\left(\frac{M_{t}^{d}}{P_{t}}\right)^{-\varepsilon}=P_{t} \lambda_{t}-E_{t} \beta P_{t+1} \lambda_{t+1} P_{t} / P_{t+1}
$$

Effort

$$
\frac{\theta h N_{t}}{\left(\tau-\chi-h e_{t}\right)}=P_{t} \lambda_{t} w_{t} N_{t}
$$

Employment

$$
E_{t} \theta \ln \left(\frac{\tau-\chi-h e_{t+1}}{\tau}\right)=-E_{t} P_{t+1} \lambda_{t+1} w_{t+1} e_{t+1}
$$

Utilisation

$$
r_{t}=\delta \phi U_{t}^{\phi-1}
$$

Capital

$$
0=-P_{t} \lambda_{t}+E_{t} \beta P_{t+1} \lambda_{t+1}\left[1+r_{t+1} U_{t+1}-\delta U_{t+1}^{\phi}\right]
$$

Bonds

$$
0=-P_{t} \lambda_{t}+E_{t} \beta P_{t+1} \lambda_{t+1}\left[1+R_{t}\right] P_{t} / P_{t+1}
$$




\section{Appendix 2: Loglinearized conditions}

Note that output, capital, consumption, investment, real money balances, and the Lagrange multiplier are adjusted for growth. The system of equations that solve the model is given by:

Consumption

$$
-\hat{c}_{t}-\hat{\psi}_{t}=0
$$

\section{Effort}

$$
\widehat{\psi}_{t}+(1-\alpha) \hat{k}_{t}+(1-\alpha) \hat{u}_{t}-(1-\alpha) \hat{n}_{t}-\left[1-\alpha+\frac{e h}{\tau-\chi-e h}\right] \hat{e}_{t}+\widehat{m c}_{t}-(1-\alpha) v_{t}=0
$$

\section{Employment}

$$
0=E_{t}\left[(1-\alpha) \hat{k}_{t+1}+(1-\alpha) \hat{u}_{t+1}-(1-\alpha) \hat{n}_{t+1}-(1-\alpha) \hat{e}_{t+1}+\widehat{\psi}_{t+1}+\widehat{m c}_{t+1}\right]
$$

Utilisation

$$
(1-\alpha-\phi) \hat{u}_{t}-\alpha \hat{k}_{t}+\alpha \hat{v}_{t}+\alpha \hat{n}_{t}+\alpha \hat{e}_{t}+\widehat{m c}_{t}=0
$$

\section{Capital}

$\frac{1}{\beta} \widehat{\psi}_{t}=\frac{1}{\beta} E_{t} \hat{\psi}_{t+1}+E_{t}\left[\left(\frac{(1-\alpha) y^{s s}}{k^{s s}}(1-\alpha)-\frac{\delta \phi}{\gamma_{x}}\right) \hat{u}_{t+1}-\frac{(1-\alpha) y^{s s}}{k^{s s}}\left(\alpha \hat{k}_{t+1}-\alpha \hat{n}_{t+1}-\alpha \hat{e}_{t+1}-\widehat{m c}_{t+1}\right)\right]$

\section{Euler Equation}

$$
\widehat{\psi}_{t}-z_{t}=E_{t} \widehat{\psi}_{t+1}
$$




$$
R_{t}-z_{t}=E_{t} \pi_{t+1}
$$

Money demand

$$
\frac{1}{\varepsilon} \hat{c}_{t}-\widehat{r m}_{t}-\frac{1}{\varepsilon} \frac{1}{R^{s s}} R_{t}=0
$$

Capital Law of Motion

$$
(1-\delta) \hat{k}_{t}-\delta \phi \hat{u}_{t}+\left(\gamma_{x}-1+\delta\right) \hat{i}_{t}-(1-\delta) \hat{v}_{t}=\gamma_{x} \hat{k}_{t+1}
$$

Resource Constraint

$$
\left[1-\alpha+\frac{k^{s s}}{y^{s s}} \frac{(1-\delta)}{\gamma_{x}}\right]\left(\hat{k}_{t}-\hat{v}_{t}\right)+\left[1-\alpha-\frac{k^{s s}}{y^{s s}} \frac{\delta \phi}{\gamma_{x}}\right] \hat{u}_{t}+\alpha \hat{n}_{t}+\alpha \hat{e}_{t}-\frac{c^{s s}}{y^{s s}} \hat{c}_{t}-\frac{g^{s s}}{y^{s s}} \hat{g}_{t}=\frac{k^{s s}}{y^{s s}} \hat{k}_{t+1}
$$

Production Function

$$
\hat{y}_{t}-(1-\alpha) \hat{k}_{t}-(1-\alpha) \hat{u}_{t}+(1-\alpha) \hat{v}_{t}-\alpha \hat{n}_{t}-\alpha \hat{e}_{t}=0
$$

Calvo Pricing

$$
\pi_{t}-\alpha_{\varepsilon} \widehat{m c}_{t}=\beta E_{t} \pi_{t+1}
$$

Money supply process

$$
\widehat{r m}_{t-1}+\widehat{\mu}_{t}-\frac{1}{\varepsilon} \hat{v}_{t}-\widehat{r m}_{t}-\pi_{t}=0
$$

Hatted variables denote log-deviations from their steady state values. The variable $\psi_{t}$ denotes the nominal Lagrange multiplier $P_{t} \lambda_{t}$, adjusted for growth. $\pi_{t}$ is the demeaned quarterly net inflation rate, and $R_{t}$ and $z_{t}$ denote the de-meaned net nominal and real interest rates, respectively.

The 13 equations describe the path of 13 endogenous variables: output $\left(\hat{y}_{t}\right)$, utilisation $\left(\hat{u}_{t}\right)$, capital $\left(\hat{k}_{t}\right)$, effort $\left(\hat{e}_{t}\right)$, employment $\left(\hat{n}_{t}\right)$, consumption $\left(\hat{c}_{t}\right)$, investment $\left(\hat{i}_{t}\right)$, nominal money balances $\left(\widehat{r m}_{t}\right)$, the nominal interest rate $\left(R_{t}\right)$, the real interest rate $\left(z_{t}\right)$, the Lagrange multiplier $\left(\widehat{\psi}_{t}\right)$, real marginal cost $\left(\widehat{m c}_{t}\right)$, and inflation $\left(\pi_{t}\right)$. 


\section{Appendix 3:}

\begin{tabular}{|c|c|c|c|c|}
\hline \multicolumn{1}{|l|}{ Table 2: Parameter values for different nested model variants } \\
\hline Parameter & $\begin{array}{l}\text { 1-factor input } \\
\text { model with no } \\
\text { capital }\end{array}$ & $\begin{array}{l}\text { 2-factor input } \\
\text { model with } \\
\text { capital and } \\
\text { labour }\end{array}$ & $\begin{array}{l}\text { Variable } \\
\text { capital } \\
\text { utilisation } \\
\text { model }\end{array}$ & $\begin{array}{l}\text { Variable } \\
\text { labour } \\
\text { utilisation } \\
\text { model }\end{array}$ \\
\hline$\theta$ & 2.1 & 2.1 & 2.1 & 3.89 \\
\hline$h$ & 1 & 1 & 1 & 324.8 \\
\hline$\chi$ & 0 & 0 & 0 & 60 \\
\hline$\tau$ & 1 & 1 & 1 & 1369.2 \\
\hline$\phi$ & 10000 & 10000 & 1.56 & 1 \\
\hline$e$ & 0.33 & 0.33 & 0.33 & 0.8 \\
\hline$U$ & 1 & 1 & 1 & 0 \\
\hline$N$ & 0 & $\begin{array}{l}\text { =0 no capital } \\
\text { adj costs } \\
=19.4 \text { w/ } \\
\text { capital adj } \\
\text { costs }\end{array}$ & & \\
\hline$b$ & 1 & & & \\
\hline
\end{tabular}

